\title{
Endüstri 4.0 Dönüşüm Sürecinde, KOBİ’lerin Teknoloji Seviyelerinin Belirlenmesi: Konya İmalat Sanayi Örneği
}

\author{
Defining Technology Levels of SMEs in Transition to Industry 4.0: The Case of Konya \\ Manufacturing Industry
}

\author{
Büşra YİĞíTOL ${ }^{1}$ (i), Hasan Kürşat GÜLEŞ ${ }^{2}$, Tuğba SARI ${ }^{1}$ \\ ${ }^{1}$ Konya Glda ve Tarım Üniversitesi, Yönetim Bilişim Sistemleri Bölümü, 42080, Konya, Türkiye \\ ${ }^{2}$ Konya Gıda ve Tarım Üniversitesi, Uluslararası Ticaret ve İşletmecilik Bölümü, 42080, Konya, Türkiye
}

\section{$\ddot{\mathbf{O}} \mathbf{z}$}

İçinde bulunduğumuz çağda, deneyimlediğimiz dijitalleşme süreci, ülkelerin ekonomik sürdürülebilirliklerinin temel unsurlarından biri haline gelmiştir. Bu çerçevede Endüstri 4.0 teknolojilerine uyum, günümüz ve gelecekte işletmelerin sürdürülebilirliklerini belirleyecek kritik faktörlerden biri olarak karşımıza çıkmaktadır. Yeni teknolojilere uyum sağlamada karşılaşılan zorluklar, büyük ölçekli işletmelerin yanı sıra belki de en fazla küçük ölçekli işletmeler için tehdit oluş̧urmaktadır. Çünkü küçük ve orta ölçekli işletmeler (KOBİ'ler) dijitalleşme altyapısı için gerek duyulan bilgi ve beceri, insan kaynağı, yatırım finansmanı gibi kaynaklara erişmekte daha dezavantajlı konumdadır. Dolayısıyla Türkiye gibi ülke ekonomisinin ve istihdamının büyük çoğunluğunun KOBI’'lere dayandığı gelişmekte olan ülkelerde bu geçiş sürecinin nasıı sağlanacağı önemli bir sorundur. Bu açıdan KOBI'’lerin teknoloji seviyelerinin belirlenmesi, bu yönde ekonomik ve politik yaklaşımların geliştirilmesi açısından önemlidir. Bu çalışmada Konya ili imalat sanayiinde faaliyet gösteren KOBİ’lerin geleneksel bilişim ve imalat teknolojileri ile yeni tanıtılan Endüstri 4.0 teknolojilerini uygulama düzeylerinin belirlenmesi amaçlanmıştır. $\mathrm{Bu}$ kapsamda Konya merkezinde faaliyet gösteren 185 imalatçı KOBİ ile yapılan görüşmeler sonucunda elde edilen veriler istatistiki açıdan değerlendirilmiştir. Çalışma sonuçlarına göre bölgedeki işletmelerin bilişim ve imalat teknoloji kullanım düzeyleri göreceli olarak olumlu bir düzeyde seyir ederken, aynı işletmelerin Endüstri 4.0 teknolojileri açısından düşük bir uygulama düzeyine sahip oldukları görülmektedir. Ayrıca, örnekleme dâhil edilen işletmeler bazı teknolojilerin kullanımı konusunda kendilerini olduklarından daha yetkin görmektedir. Çalı̧̧̧anın diğer önemli sonuçlarından biri ise, Endüstri 4.0 teknolojilerini uygulama düzeyleri düşük olmasına rağmen işletmelerin bu teknolojileri sektörün ve işletmelerin geleceği açısından önemli yönde atfetmeleridir.

Anahtar kelimeler: Endüstri 4.0, İmalat Sanayi, KOBİ, Teknoloji düzeyi

\begin{abstract}
In this era of digitalization, technological developments we have experienced has become one of the basic elements of the economic sustainability of countries. In this context, compliance with Industry 4.0 technologies is one of the critical factors that will determine the sustainability of companies in the present and the future. Challenges in adapting to new technologies has threaten small-sized companies the most. This is because small and medium-sized enterprises (SMEs) are more disadvantageous in accessing resources such as knowledge and skills, human resources and financial investment needed for the digitalization infrastructure. Thus, in developing countries such as Turkey where the economy and employment is mainly depend on small and medium-sized enterprises, how to ensure this transition successfully is a major problem. In this respect, determining technology levels of SMEs is important for establishing economic and political policies. In this study, it is aimed to determine the application level of traditional information and manufacturing technologies; and state of the art Industry 4.0 technologies of SMEs operating in Konya manufacturing industry. In this context the impact of the transition from Industry 3.0 technologies to Industry 4.0 on SMEs have been analyzed. The data was obtained from 185 SMEs with face-to-face interviews were analyzed statistically. According to the results of the study, while traditional IT and manufacturing technology usage levels of the companies re relatively positive, the firms have a low level of application in terms of Industry 4.0 technologies. In addition, the sample companies overestimated themselves in using certain technologies. Another important result of the study is that, although the mean application levels of Industry 4.0 technologies are quite low, firms attribute these technologies as very important for their sector and for themselves.
\end{abstract}

Keywords: Industry 4.0, Manufacturing Industry, SMEs, Technology level 


\section{GİRIŞ}

Günümüz iş dünyası gerek teknolojik yenilikler gerekse üretkenliği artırma yönündeki tetikleyici diğer dinamikler sebebiyle yeni bir ekonomik sistem içerisine doğru sürüklenmektedir. Bu değişimler sanayi tarihinin başlangıcı olarak kabul edilen 18. yy'den bu yana gerçekleştirilen ilerlemeler ile yol almaktadır. Tarihsel süreç içerisindeki ilk paradigma değişimi 1760'lı yıllarda başlayıp 1830'lara kadar süren dönemde yaşanmıştır. $\mathrm{Bu}$ dönemde su ve buhar gücünün üretim süreçlerinde kullanılmaya başlanmıştır. Üretimde makineleşme süreci ilk olarak İngiltere de ortaya çıkmasına rağmen kısa sürede Avrupa'ya yayılmıştır. $\mathrm{Bu}$ dönemde yaşanan gelişmeler sadece üretimi artırmakla kalmamış toplumsal yaşam kalitesini de artırmıştır. Üretimde mekanikleşmenin yaygınlaşmaya başlamasıyla sanayi sistemi, beden gücünden makine gücüne doğru bir geçiş yaşamıştır. Ayrıca kömürün yanı sıra buhar gücünden yararlanılması ve bu sayede demiryolu kullanımının yaygınlaşması ile yeni hammadde kaynaklarına ulaşım kolaylaşmış ve ağır sanayii gelişim göstermiştir [1].

Sanayi tarihinin ikinci dönüm noktası ise 1840'lı yıllarda elektriğin sanayi sisteminde kullanılmaya başlanmasıyla yaşanmıştır. İkinci Endüstri Devrimi başta her ne kadar Amerika, Japonya, Almanya gibi öncü ülkelerde ortaya çıksa da zaman içerisinde birçok ülkeye yayllım göstermiştir [2]. Elektriğin üretim süreçlerinde kullanılması daha çok ve daha hızlı bir üretim gerçekleştirilmesinin de yolunu açmıştır. Bu gelişmenin ilk örneğini Henry Ford otomotiv sektöründe kullanılmak üzere geliştirdiği bant tipi üretim ile ortaya koymuş ve bu üretim tarzı devrim niteliğinde görülmüştür [3]. İlk olarak otomotiv sektöründe kullanılsa da zaman içerisinde birçok fabrikada üretim, montaj hatlarının kurulmasıyla hızlanmış ve verimlilik artışı sağlanmıştır.

Montaj hattı ve seri üretim ile ivme kazanan üretim altyapısı bilgisayarın icadı ile yeni bir döneme adım atmıştır. Üçüncü sanayi devrimi olarak tanımlanan bu dönemde dijital teknolojilerde gelişim yaşanmış ve bilgisayar ve iletişim teknolojileri hem toplumsal alanda hem de iş hayatında kullanılmaya başlanmıştır. Üçüncü sanayi devriminde yaşanan gelişmeler ile birlikte emek kavramı yerini mekanik süreçlere bırakırken örgüt içerisindeki insan da üretimin bir dişlisi olmaktan ziyade beyni olmak yolunda bir değer artışı yaşamaya başlamışıı. Teknolojik gelişmelerin geldiği son noktada ise artık Endüstri ve üretim süreçlerinde dijitalleşme kavramından söz edilmeye başlanmıştır. Bu dönem Endüstri 4.0 yani dördüncü sanayi devrimi olarak tanımlanmaktadır. Henüz başlangıç aşamasında olan bu dönem üretim sürecindeki tüm aktörlerin birbiri ile koordineli iletişimini, verilerin anlık ve doğru şekilde teminine olanak tanıyarak katma değeri yüksek bir üretim sürecinin oluşturulmasına olanak tanımaktadır [4].
Endüstri 4.0 kavramının temelleri 2011 yilında Almanya'da düzenlenen teknoloji fuarında ortaya atılmıştır [5]. Endüstri 4.0 ile üretim sistemlerinde akillı makine, robot sistemleri ve sensörlerin kullanılması, böylelikle süreçlere ve makinalara ilişkin anlık veri sağlama avantajı ile üretimin daha kontrollü, daha hızl, daha verimli ve daha az maliyetli olmasını sağlayan bir devrim ya da diğer ifadeyle gelecek öngörüsünden bahsedilmektedir. Akıllı üretim sistemleri ile işletmelerin üretimleri küresel düzeye yükselir ve böylece üretim ya da talep ile ilgili değişikliklere hızla yanıt verebilecek kadar esneklik kazanmış olurlar [6]. Kısaca Endüstri 4.0 ile birlikte yeni teknolojilerden ve aşağıda belirtilen kavramların potansiyellerinden yararlanmak amaçlanmaktadır [7];

- İnternet ve nesnelerin interneti teknolojilerinin ulaşılabilirliği ve kullanımı

- Teknik süreçler ile iş süreçlerinin entegrasyonun sağlanması

- Üretim süreçlerinin gerçek dünyadan dijital dünyaya aktarımı ve sanallaştırılabilmesi

- Akıllı Endüstriyel üretim ve akıllı ürünleri içeren akıllı fabrikaların kullanılması

Endüstri 4.0 ile beraber gündeme gelen 9 teknoloji siniflandırması bulunmaktadır. $\mathrm{Bu}$ teknolojiler işletmelerin sanayi dönüşümünde belirleyici kriterler olarak da görülmektedir. Bunlar büyük veri, bulut teknolojileri, nesnelerin interneti, siber güvenlik, artırılmış gerçeklik, eklemeli üretim, yatay ve dikey bütünleşme, otonom robotlar ve benzetim teknolojileridir [17]. Bazı kaynaklarda bu teknolojik siniflandırmaya siber fiziksel sistemler de dâhil edilmektedir [18, 35]. Bu teknolojilerin ne olduğu ve işletmeler açısından gelecek öngörüsünde nasıl etkin kullanıldığı önemli bir olgudur.

- Büyük Veri üretim ve genel süreçler ile ilişkin çeşitli kaynaklardan sağlanan geniş, karmaşık, çeşitli ve heterojen verilerin bir birleşim kümesini ifade etmektedir [8]. Üretim sürecinin hızlı, kaliteli ve etkin yönetiminin en temel noktası elde edilen verilerin anlık, gerçek zamanlı olarak işlenebilmesi ve kullanıma hazır hale gelebilmesidir.

- Bulut Bilişim teknolojileri sayesinde büyük veri kümelerinin etkin yönetimi ve depolanması sağlanabilmektedir. Özellikle akillı fabrikalarda üretilen ve birbirinden farklı birçok kaynaktan sağlanan fazla miktarlardaki verilerin anlık olarak kullanıma hazır halde depolanması için elverişli bir teknolojidir. Geleneksel depolama hizmetlerinden farklı olarak, bulut teknolojileri, çeşitli kaynaklardan gelen büyük miktarda veri için daha küçük bir alanda depolama alanı sağlar $[9,10]$.

- Siber Güvenlik, dijitalleşme ile ilgili belki de en önemli soru işareti verilerin güvenliğinin sağlanmasında öncü uygulamaların başında 
yer almaktadır. Özellikle internet kullanımına bağlı olarak, üretim araçları ve dijital sistemler arasında bağlanırlılığın artması siber güvenlik endişesini artırmakta ve makinelere erişimin etkin yönetilmesinde güvenli bağlantı önem kazanmaktadır [11].

- Artırılmış Gerçeklik teknolojileri dış dünyadaki gerçek bir görüntünün sanal semboller ile yansitılmasina dayanan bilgisayar grafik tekniği olarak tanımlanabilir [12].

- Eklemeli Üretim Teknolojileri en basit tanımıyla başlangıçta üç boyutlu bir bilgisayar destekli tasarım sistemi kullanılarak oluşturulan bir modelin, süreç planlama ihtiyacı olmadan doğrudan üç boyutlu yazıcılar yardımı ile üretilebilmesidir [13]. $\mathrm{Bu}$ teknoloji sayesinde, karmaşık bir üretim süreci gerektiren bir ürünün üretimi, geleneksel yöntemlere kıyasla çok daha kolay olarak gerçekleştirilebilmektedir.

- Yatay ve Dikey Bütünleşme teknolojileri ile işletmeler yatay entegrasyonla, farklı işletmeler arasındaki bilgileri, finansal kaynakları ve materyalleri paylaşmak için etkili bir ekosistem oluşturulabilirken, dikey entegrasyon ile elastik ve yeniden yapılandırılmış üretim sistemleri elde edebilirler [14].

- Otonom Robot güvenli, esnek, çok yönlü ve işbirliğine odaklanarak görevleri akıllıca tamamlayabilen robotların desteklediği özerk üretim yöntemlerindendir [15]. Akıllı farikalarda hem robotların hem de insan gücünün kullanılmasıyla işbirliği ortamı sağlanabilmekte ve ağır fiziksel güç gerektiren işlemler robotlar tarafindan güven ve kalite ile gerçekleştirilebilmektedir.

- Benzetim Teknolojileri ile üretim süreçleri fiziksel fabrikalardan sanal ortamlara aktarılabilmektedir. Böylece test, kurulum, bakım ve kullanım ile ilgili birçok sürecin sanal platformlarda test edilebilmesi ve iyileştirme çalışmalarının maliyet açısından fayda sağlayacak şekilde gerçekleştirilmesine olanak sağlanabilmektedir.

- Nesnelerin interneti (IoT) fiziksel zeki nesneler olarak tanımlanmaktadır [16]. $\mathrm{Bu}$ yapı sayesinde, cihazlar birbirleriyle iletişim kurabilir ve birbirleriyle etkileşime girebilir ve karar verme merkezi yapıdan uzaktır [17].

- Siber Fiziksel Sistemler (CPS), fiziksel varlıklar ve bilgisayar teknolojileri arasındaki birbirine bağlı sistemleri yönetmek için dönüştürücü teknolojiler olarak tanımlanmaktadır [18].

İşletmeler belirtilen teknolojik sistemleri kullanarak Endüstri 4.0 devriminin sağlayacağı birçok avantajdan yararlanabilmektedir. Bu avantajların bazıları şöyle siralanabilmektedir;

- Üretim sisteminin etkin izlenebilirliği ve kontrolüne imkân verir, böylelikle oluşabilecek muhtemel sıkıntıların önüne geçilebilmektedir,

- Üretimde sıfir hata ile maliyet avantajı sağlar,

- Üretim süreçlerinin müşteri istek ve ihtiyaçlarına göre esneklik kazanmasına imkân sağlar,

- Kaynak yönetiminde geleneksel üretim sistemlerine kıyasla daha etkin ve verimlilik sağlar. Kaynakların neredeyse sıfir atık ile kullanımına imkân verir,

- Üretim süreçlerinde kaynak tasarrufu sağlar ve üretimin çevreye duyarlı bir şekilde yürütülmesine katkı sağlar.

Tüm bu teknolojik gelişmeler ve işletmelere sağladığı yararlar günümüz ve gelecek rekabet şartlarını dinamik bir boyuta taşımaktadır. Dolayısıyla işletmelerin bu gelişmeleri takip etmeleri ve kendilerini dijitalleşme yolculuğunda hazır hale getirmeleri gerekmektedir. $\mathrm{Bu}$ yolculukta büyük ölçekli işletmeler uyum ve geçiş konusunda küçük ölçekli işletmelere oranla daha avantajlı bir konuma sahiptir. Küçük ölçekli işletmeler için bilgi ve iletişim teknolojilerindeki değişiklikler, yeni iş modelleri gibi çevresel dinamikler düşünüldüğünde ve bu faktörlere işletmelerin yapısal sorunları, bilgi ve beceri eksiklikleri de eklendiğinde dönüșüm sürecinin ne kadar zorlu geçeceği tahmin edilebilmektedir. Ancak üretim sanayiinin çok büyük bir yüzdesini oluşturan ve böylelikle başlıca ekonomik yap1 taşlarından biri olan küçük ölçekli işletmelerin değişim sürecindeki rolleri merak konusudur. Dolayısıyla KOBİ'leri dönüşüm sürecinin dışında tutmak ekonomik dengelerin sürdürülebilirliğinin sağlanmasında olumsuz sonuçlar doğuracaktır. KOBI'lerin bu sürece nasıl entegre edileceği yönünde yeni adımların atılması ve gerek politik gerekse ekonomik sistemlerin bu konu üzerine yeni yaklaşımlar geliştirmeleri gerekmektedir. $\mathrm{Bu}$ sürecin ilk aşaması ise KOBI'lerin mevcut durumlarının etkin tespiti ile mümkündür. Geleceğe yönelik olarak sürecin etkin işleyebilmesi ve çözüm önerileri üretebilmek için KOBI'lerin mevcut teknolojik düzeylerin belirlenmesi yararlı olacaktır. Elbette ki işletmelerin mevcut düzeyin belirlenmesinde Endüstri 4.0 teknolojilerini kullanım durumları önemli bir göstergedir.

$\mathrm{Bu}$ amaçla bu çalışmada Konya ili imalat sanayinde faaliyet gösteren KOBİ'lerin teknoloji uygulama düzeylerinin çok boyutlu olarak belirlenmesi amaçlanmaktadır. Çalışmada KOBI'lerin mevcut imalat ve bilişim teknolojilerini kullanım düzeylerinin yanı sıra, yeni gelişmekte olan Endüstri 4.0 teknolojilerini uygulama düzeylerinin de belirlenmesi hedeflenmiştir. Endüstri 4.0 teknolojilerinin, hâlihazırda kullanılan imalat ve bilişim teknolojileri ile birlikte araştırılmasındaki amaç bu teknolojilerin 
KOBİ'lerin teknoloji kullanım düzeylerinin belirlemesi açısından etkin bir doğrulama sağlayacağı yönündeki kanaattir. Çünkü sanayi tarihinin geçiş sürecinde olduğu gibi teknolojik seviyenin ilerlemesi geçmiş ve geleceğin bağlantısı ile mümkündür. İşletmelerin bir üst teknoloji seviyesine yükselebilmesi alt seviye teknolojilerin kullanımında ne kadar doygunluğa eriştiği ve bu süreci ne kadar tamamladığı ile ilişkilidir.

\section{LITERATÜR TARAMASI}

Endüstri 4.0 ile ilgili literatürdeki çalışmaların sayısı, kavramın bilinirliğinin ve öneminin artması ile paralel olarak gün geçtikçe artmaktadır. Endüstri 4.0 teknolojilerine, işletmelere sağlayacağı faydalara ve işletmelerin geçiş sürecinde karşılaşacağı muhtemel zorluklara ilişkin tanımlayıcı çalışmaların yanı sıra, Endüstri 4.0 teknolojilerinin işletmelerde uygulanma seviyelerini inceleyen çalışmalar da bulunmaktadır. Türkçe literatüre bakıldığından aslında çoğu çalışmanın uygulamadan ziyade kavram ve kavrama ilişkin teknolojilerin açıklanmasına yönelik teorik çalışmalar olduğu görülmektedir [19, 20, 21, 22]. Bu çalışmada genel olarak KOBİ'ler bağlamında literatür incelemesi yapılmış ve öncü çalışmalardan bazıları Tablo 1'de özetlenmiştir.

Tablo 1. Endüstri 4.0 Literatür Taraması

\begin{tabular}{|c|c|c|}
\hline Yazar & Amaç & Yöntem \\
\hline $\begin{array}{l}\text { Safar ve diğ. } \\
\text { (2018) [23] }\end{array}$ & $\begin{array}{l}\text { KOBİ'lerin rehberlik } \\
\text { etmek amaciyla Endüstri } \\
4.0 \text { gereksinimlerine } \\
\text { göre iş organizasyon } \\
\text { modeli tasarlamak. }\end{array}$ & $\begin{array}{l}\text { Model } \\
\text { Tasarımı }\end{array}$ \\
\hline $\begin{array}{l}\text { Sevinç ve } \\
\text { diğ. } \\
{[24]}\end{array}$ & $\begin{array}{lr}\text { KOBI'lerin } & \text { Sanayi } 4.0 \text { 'a } \\
\text { geçiş } & \text { sürecindeki } \\
\text { zorluklarını } & \text { analiz } \\
\text { etmek. } & \end{array}$ & Anket \\
\hline $\begin{array}{l}\text { Schröder } \\
(2016)[25]\end{array}$ & $\begin{array}{l}\text { KOBI'lerin Endüstri } 4.0 \\
\text { ile ilgili temel } \\
\text { zorluklarına ve bu } \\
\text { çerçevede bu zorlukların } \\
\text { üstesinden gelmelerine } \\
\text { destek olmak için ilgili } \\
\text { çerçevenin } \\
\text { uyarlanması gerektiği } \\
\text { belirlemek. }\end{array}$ & $\begin{array}{l}\text { Literatür } \\
\text { Çalışması }\end{array}$ \\
\hline
\end{tabular}

\begin{tabular}{llll}
\hline Çevik & KOBI’lerin & Sanayi 4.0 & Anket \\
(2019) [26] & ile dönüşüm sürecindeki & \\
& hazırlık durumlarını & \\
& incelemek.
\end{tabular}

\begin{tabular}{|c|c|c|c|}
\hline \multirow[b]{2}{*}{$\begin{array}{l}\text { Mittal ve } \\
\text { diğ. } \quad(2018) \\
{[27]}\end{array}$} & & & \\
\hline & $\begin{array}{l}\text { KOBİ'lerin bağlamında } \\
\text { mevcut sistemleri, } \\
\text { Endüstri } 4.0 \text { olgunluk } \\
\text { modellerini analiz etmek } \\
\text { ve KOBI'lerin bu süreç } \\
\text { içerisindeki ör } \\
\text { gereksinimleri } \\
\text { belirlemek. }\end{array}$ & $\begin{array}{l}\text { Literatür } \\
\text { Çalışması }\end{array}$ & $\begin{array}{l}\text { Çalışma sonuçlarına göre dijital dönüşüm sürecinde } \\
\text { KOBİ'lerin spesifik gerekliliklerini ve zorluklarını } \\
\text { yansıtan çalışmalar sınırlı kalmıştır. }\end{array}$ \\
\hline $\begin{array}{l}\text { Schumacher } \\
\text { ve diğ. } \\
(2016)[28]\end{array}$ & $\begin{array}{l}\text { Endüstri } \\
\text { olgunluğunu } \\
\text { değerlendirmek için bir } \\
\text { model ve uygulama } \\
\text { sunmak. }\end{array}$ & $\begin{array}{l}\text { Model } \\
\text { Tasarımı }\end{array}$ & $\begin{array}{l}\text { Model } 9 \text { boyut ve } 62 \text { maddeden oluşmaktadır. Bu } \\
\text { boyutlar çalışanlar, kültür, ürünler, liderlik, müşteriler, } \\
\text { teknoloji, strateji, yönetişimdir. İlk dört boyut, temel } \\
\text { sağlayıcıların değerlendirilmesi için, diğerleri ise } \\
\text { organizasyonel unsurların değerlendirilmesi içindir. }\end{array}$ \\
\hline $\begin{array}{l}\text { Müller ve } \\
\text { Voigt (2018) } \\
\text { [29] }\end{array}$ & $\begin{array}{l}\text { Nesnelerin interneti } \\
\text { teknolojilerinin } \\
\text { ekonomik, sosyal ve } \\
\text { ekolojik olmak üzere üç } \\
\text { boyutlu }\end{array}$ & & $\begin{array}{l}\text { Almanya (222 işletme) ve Çin'den (107 işletme) } \\
\text { toplamda } 329 \text { KOBİ ile görüşmeler sağlanmıştır. } \\
\text { Çalışma sonuçları Almanya'daki KOBİ'lerin Endüstri } \\
4.0 \text { kavramını ve sürecini daha çok büyük ölçekli } \\
\text { işletmelere yönelik olarak değerlendirdiğini }\end{array}$ \\
\hline
\end{tabular}




\begin{tabular}{|c|c|c|c|}
\hline Yazar & Amaç & Yöntem & Sonuç \\
\hline & $\begin{array}{l}\text { değerlendirilmesini } \\
\text { sunmak. }\end{array}$ & & $\begin{array}{l}\text { gösterirken, Çin'deki işletmelerin ise kavramın sosyal } \\
\text { faydalarına ağırlık verdiğini saptamaktadır. }\end{array}$ \\
\hline $\begin{array}{l}\text { Özçelik ve } \\
\text { diğ. (2018) } \\
{[30]}\end{array}$ & $\begin{array}{lr}\text { Makine } & \text { imalat } \\
\text { sektöründe } & \text { dijital } \\
\text { olgunluk } & \text { seviyesini } \\
\text { ölçmek. } & \end{array}$ & Anket & $\begin{array}{l}\text { Çalışma Sakarya ilinde bir imalat işletmesinde } \\
\text { yürütülmüştür. Literatürden dijitalleşme endeksi } \\
\text { ölçümü için } 9 \text { ölçüt ele alınarak hazırlanan soru formu } \\
\text { uygulamaya alınmıştır. Analitik Hiyerarşi Prosesi } \\
\text { yöntemi kullanılarak değerlendirilen dijitalleşme } \\
\text { endeksi sonuçlarına göre uygulama yapılan işletmenin } \\
5 \text { seviyeli olgunluk modeli üzerinden yaklaşı olarak } \\
\text { 3. seviyede olduğu belirlenmiştir. }\end{array}$ \\
\hline
\end{tabular}

\begin{tabular}{|c|c|}
\hline $\begin{array}{l}\text { TUSİAD ve } \\
\text { BCG (2016) } \\
{[11]}\end{array}$ & $\begin{array}{l}\text { Endüstri } 4.0 \text { tarafindan } \\
\text { sunulan firsatları } \\
\text { incelemek, Türkiye } \\
\text { sanayisinin potansiyelini } \\
\text { ortaya koymak. }\end{array}$ \\
\hline
\end{tabular}

Yapılan görüşme sonuçlarında, Türkiye'de zaten Endüstri 4.0 yönünde atılmış bazı somut adımların olduğu gözlenmiştir. Endüstri 4.0 teknolojilerinden yararlanma ve Türkiye'de rekabet avantajı yaratma konusunda sektörde yüksek düzeyde farkındalık ve ilginin olduğu kabul edilmektedir. Raporda, sektörlerin işgücü yapısı, teknoloji altyapısı ve yatırım gibi sorunlarından kısaca bahsedilmektedir. Raporun son bölümünde, Türkiye için bir yol haritası hazırlamanın önemi ve katılımcılar için ortak bir platform üzerinde tartışma yapılması gerektiği vurgulanmıştır.

\begin{tabular}{|c|c|c|}
\hline $\begin{array}{l}\text { Infosys } \\
(2015)[31]\end{array}$ & $\begin{array}{l}\text { Şirketlerin Endüstri } 4.0 \text { Anket } \\
\text { yolculuğundaki } \\
\text { planlarını incelemek. }\end{array}$ & $\begin{array}{l}\text { Görüşülen şirketlerin çoğunluğu Endüstri } 4.0 \\
\text { teknolojilerinin potansiyel gücünün farkında olmasına } \\
\text { rağmen, yalnızca birkaçı bu kavramları pratikte } \\
\text { kullanmaktadır. Ülkeler arasında bir kıyaslama } \\
\text { yapılmış ve Çin'in diğer ülkelere kıyasla lider } \\
\text { konumda olduğu söylenmiştir. Sektörler arasında } \\
\text { yapılan kıyaslama da ise süreç Endüstrisinin diğer } \\
\text { sektörlere göre lider konumda olduğu belirtilmiştir. }\end{array}$ \\
\hline $\begin{array}{l}\text { Berger } \\
(2017)[32]\end{array}$ & $\begin{array}{l}\text { Yiyecek ve içecek } \\
\text { Endüstrisinin Endüstri } \\
4.0 \text { açısından avantaj ve } \\
\text { dezavantajlarını Türkiye } \\
\text { örneği bağlamında }\end{array}$ & $\begin{array}{l}\text { Türkiye'nin dijital teknoloji uygulamalarında diğer } \\
\text { ülkelere göre sıralamasına yer verilmiştir. Raporda } \\
\text { Türkiye'nin yapılan sıralamalarda olumlu bir konuma } \\
\text { sahip olmasına rağmen, Endüstri } 4.0 \text { hazırlığında } \\
\text { düşük seviyeli ülke grubunda olduğu belirtilmektedir. }\end{array}$ \\
\hline
\end{tabular}

\begin{tabular}{|c|c|}
\hline $\begin{array}{l}\text { Deloitte } \\
(2017) \text { [33] }\end{array}$ & $\begin{array}{lrr}\text { Dünya } & \text { genelinde } & \text { Anket } \\
\text { işletmelerin Endüstri } 4.0 & \\
\text { hazırlı } & \text { durumunu } & \\
\text { değerlendirmek. } & \end{array}$ \\
\hline
\end{tabular}

$\begin{array}{lllr}\text { Europarl } & \text { Endüstri } 4.0 \text { ile ilgili } & \text { SWOT } \\ \text { Report } & \text { teknolojileri ve sürecin } & \text { Analizi } \\ \text { (2016) [34] } & \begin{array}{l}\text { zorluklarını } \\ \text { etmek. }\end{array} & \text { analiz } & \\ & & \end{array}$

Çalışma sonuçlarına göre, kamu kurumlarının toplumun yönlendirilmesinde daha etkili olduğu sonucuna varılmış ve şirketler üzerindeki en büyük etkinin müşterilere mümkün olduğunca en iyi ürün / hizmeti sunmak olduğu, son iki yılda en fazla ilgi gören konuların yeni ürün ve hizmetler geliştirmek / yaratmak ve verimliliği artırmak olduğu belirtilmiştir. Raporda, Endüstri 4.0 kavramı, zorluklar1, teknolojileri, Avrupa Birliği'nin Endüstri 4.0 için destek politikaları, siber güvenlik riskleri, teknolojik, sosyal ve iş değişiklikleri gibi konular ele alınmıştır. Çalışmada ayrıca Endüstri 4.0'a yönelik SWOT analiz gerçekleştirilmiştir.

\begin{tabular}{|c|c|c|c|}
\hline $\begin{array}{l}\text { Şahin (2019) } \\
\text { [35] }\end{array}$ & $\begin{array}{l}\text { G-20 ülkelerinin } \\
\text { Endüstri } 4.0 \text { seviyelerini } \\
\text { belirlemek ve kendi } \\
\text { aralarında karşılaştırma } \\
\text { yapmak suretiyle bir } \\
\text { sıralama oluşturmak. }\end{array}$ & $\begin{array}{l}\text { Entropi } \\
\text { Tabanli } \\
\text { COPRAS } \\
\text { Yöntemi }\end{array}$ & $\begin{array}{l}\text { Çalışmada G-20 ülkeleri çok kriterli karar verme } \\
\text { tekniklerinden bir tanesi olan COPRAS yöntemi } \\
\text { kullanılarak ülkelerin Endüstri } 4.0 \text { seviyeleri } \\
\text { karşılaştırılmıştır. Elde edilen sonuçlarda Türkiye'nin } \\
20 \text { ülke arasında } 15 \text {. Sırada olduğu tespit edilmiştir. }\end{array}$ \\
\hline $\begin{array}{l}\text { Kamber ve } \\
\text { Bolatan } \\
(2019)[36]\end{array}$ & $\begin{array}{l}\text { Türkiye'de yer alan } \\
\text { üretim işletmelerinde } \\
\text { Endüstri 4.0'a bakış açısı } \\
\text { incelemek }\end{array}$ & Anket & $\begin{array}{l}\text { Çalışmada Türkiye'deki üretim işletmeleri } \\
\text { yöneticilerinin genel ve sektörel açıdan Endüstri } 4.0 \\
\text { geçiş sürecinin gerekliliği ve işletmelere katma değer }\end{array}$ \\
\hline
\end{tabular}




\begin{tabular}{|c|c|c|}
\hline Yazar & Yöntem & Sonuç \\
\hline & & $\begin{array}{l}\text { katacağı konusunda farkında oldukları sonucuna } \\
\text { varılmıştır. }\end{array}$ \\
\hline
\end{tabular}

(Kaynak: Yazarlar tarafindan oluşturulmuştur.)

\section{METODOLOJI}

Bu çalışmanın amacı, Konya ili imalat sanayi Küçük ve Orta Ölçekli İmalat İşletmeler (KOBI)'inin mevcut imalat ve bilişim teknolojileri kullanım düzeylerinin yanı sıra Endüstri 4.0 teknolojilerini uygulama düzeylerinin belirlenmesidir. $\mathrm{Bu}$ amaç doğrultusunda Konya'da öne çıkan sektörlerden makine imalatı, otomotiv ve oto yan sanayi ürünleri imalatı, gıda ürünleri imalatı ve kimyasal imalat sanayilerinde faaliyet gösteren Küçük ve Orta Ölçekli İşletmeler (KOBI) üzerinde bir anket uygulaması gerçekleştirilmiştir. Konya ilinde makine, otomotiv, kimya ve gida imalat sanayinde faaliyet gösteren 1000 'i aşkın firma bulunmaktadır. Çalışma kapsamında bu firmaların 250'sine ulaşılmaya çalışılmış olup, 185 firmadan sağlıklı veri toplanabilmiştir. İşletme yöneticileri ile yapılan yüz yüze görüşmelerden elde edilen veriler, SPSS paket programı yardımı ile istatistiksel olarak analiz edilmiştir. Anket formu mevcut imalat ve bilişim teknolojileri ile güncel Endüstri 4.0 teknolojilerine yönelik ifadeleri kapsamaktadır. Anket formunun oluşturulmasında Görçün (2017) [37], Bülbül ve Güles (2004) [38], Tekin ve diğ. (2005) [39] ve Özkurt (2016) [40]'un çalışmaları kullanılan temel çalışmalar olup ayrıca konu ile ilgili literatürdeki diğer çalışmalar da taranmıştır.

Araştırmaya katılan işletmelerin sektörler arasındaki dağılımları Tablo 2'de belirtilmiştir. Buna göre işletmelerin \%51,6's1 faaliyetlerini Makine imalat sektöründe yürütürken, işletmelerin \%31,3’ü Otomotiv imalat sektöründe faaliyet göstermektedir.
Tablo 2. Sektörlere göre KOBİ dağılımları

\begin{tabular}{lll}
\hline Sektörler & $\begin{array}{l}\text { İşletme } \\
\text { sayısı }\end{array}$ & $\begin{array}{l}\text { Yüzde } \\
(\boldsymbol{\%})\end{array}$ \\
\hline Makine & 94 & 51,6 \\
Otomotiv & 57 & 31,3 \\
Kimya & 16 & 8,8 \\
Gida & 15 & 8,2 \\
Toplam & 182 & 100,0 \\
\hline
\end{tabular}

Araştırmanın örneklemi oluşturulan KOBI'lerin ölçek/çalışan sayıları dağılımları Tablo 3'de belirtilmiştir. İşletmelerin çoğunluğunun $(\% 61,7) 10$ 49 arasında çalışana sahip olduğu görülmektedir. Bu sıralamayı \%21,9 oranı ile 1-9 çalışana sahip KOBI'ler gelmektedir.

Tablo 3. Çalışan sayılarına göre KOBİ dağılımları

\begin{tabular}{lll}
\hline Çalışan sayısı & İşletme sayısı & Yüzde $(\boldsymbol{\%})$ \\
\hline $1-9$ çalışan & 40 & 21,9 \\
$10-49$ çalışan & 113 & 61,7 \\
$50-249$ çalışan & 30 & 16,4 \\
Toplam & 183 & 100,0 \\
\hline
\end{tabular}

KOBI'lerin imalat teknolojilerini kullanım durumlarının belirlenebilmesi için çeşitli imalat sistemleri kullanım durumlarını belirtmeleri istenmiştir. Firmalara sunulan imalat teknolojileri, Bülbül ve Güleş’in 2004 yılında yaptıkları çalışma baz alınarak belirlenmiştir [38]. Bu teknolojilerin kullanım düzeylerine ilişkin veriler Tablo 4'de özetlenmiştir. Elde edilen sonuçlar değerlendirildiğinde, işletmelerin orta ve üzeri seviyede kullandığg imalat teknolojilerinin gıda ve içecek imalatı sektöründe üretim kaynakları planlaması sistemleri, makine imalat sektöründe tam zamanında üretim sistemleri, otomotiv sektöründe bilgisayar kontrollü tezgâhlar (CNC) ve tam zamanında üretim sistemleri, kimya sektöründe ise yine tam zamanında üretim sistemleri olduğu görülmektedir.

Tablo 4. İşletmelerin imalat teknolojileri kullanım düzeyleri*

\begin{tabular}{|c|c|c|c|c|c|c|}
\hline İmalat teknolojileri & & Gida & Makine & Otomotiv & Kimya & $\begin{array}{l}\text { Genel } \\
\text { ortalama }\end{array}$ \\
\hline \multirow{2}{*}{ Bilgisayar kontrollü tezgâhlar $(\mathrm{CNC})^{* *}$} & Ortalama & 2,67 & 3,18 & 4,02 & 2,75 & 3,36 \\
\hline & Std. Sapma & 1,915 & 1,697 & 1,420 & 1,612 & 1,682 \\
\hline \multirow{2}{*}{ Bilgisayar destekli tasarım $(\mathrm{CAD})^{* *}$} & Ortalama & 3,13 & 3,51 & 3,82 & 2,44 & 3,48 \\
\hline & Std. Sapma & 1,767 & 1,584 & 1,490 & 1,590 & 1,604 \\
\hline \multirow{2}{*}{ Bilgisayar destekli üretim (CAM)** } & Ortalama & 2,80 & 3,22 & 3,58 & 2,38 & 3,23 \\
\hline & Std. Sapma & 1,699 & 1,641 & 1,523 & 1,310 & 1,608 \\
\hline \multirow{2}{*}{ Esnek imalat sistemleri } & Ortalama & 2,93 & 3,06 & 3,04 & 2,63 & 3,01 \\
\hline & Std. Sapma & 1,900 & 1,501 & 1,584 & 1,586 & 1,559 \\
\hline \multirow{2}{*}{ Grup teknolojisi** } & Ortalama & 2,27 & 1,77 & 2,40 & 2,13 & 2,04 \\
\hline & Std. Sapma & 1,438 & 1,102 & 1,237 & 1,310 & 1,218 \\
\hline \multirow{2}{*}{ Üretim kaynakları planlaması } & Ortalama & 3,47 & 3,07 & 3,42 & 2,81 & 3,19 \\
\hline & Std. Sapma & 1,457 & 1,289 & 1,336 & 1,276 & 1,322 \\
\hline \multirow{2}{*}{ Tam zamanında üretim ${ }^{\mathrm{a}}$} & Ortalama & 3,27 & 3,68 & 4,02 & 3,94 & 3,77 \\
\hline & Std. Sapma & 1,624 & 1,246 & 1,110 & 1,237 & 1,248 \\
\hline İleri İmalat Teknolojileri & Ortalama & 1,93 & 2,31 & 2,82 & 2,00 & 2,41 \\
\hline Sistemleri (MRP,MRPII)** & Std. Sapma & 1,335 & 1,360 & 1,441 & 1,155 & 1,391 \\
\hline
\end{tabular}


* 1: Hiç uygulamıyor/ 5: İleri seviyede uyguluyor

**ANOVA test sonucuna göre 0,05 seviyesinde sektörler arasında anlamlı farklılık göstermektedir.

${ }^{\text {a }}$ Tam zamanında üretim, işletmelerin üretime hazırlık zamanında ve sipariş süresinde tasarruf yapmasını sağlayan, aynı zamanda ürün kalitesine odaklanan bir üretim teknolojisidir [38].

Mevcut teknolojik seviyenin belirlenebilmesinde imalat teknolojilerinin yanı sıra işletmelerin bilişim teknolojileri kullanım düzeylerinin de önemli bir gösterge olacağı düşünülmektedir. Çalışmaya dahil edilen bilişim teknolojileri, Tekin vd.'lerinin 2005 yılında yaptığı çalışma temel alınarak oluşturulmuştur [39]. Bu açıdan araştırma kapsamındaki KOBI'lerin bilişim teknolojileri kullanım düzeyleri Tablo 5'de belirtilmiştir. Sonuçlar incelendiğinde tüm sektörler içerisinde internet teknolojisinin ileri düzey kullanıma sahip olduğu görülmektedir. Çağımız işletmelerinin teknoloji seviyesi düşünüldüğünde bu sonuç çok şaşırtıcı görülmemektedir. En düşük uygulama seviyesini gösteren sistemler ise sektörler arasında farklılık göstermektedir. Gıda ve içecek imalatı sektöründe en düşük uygulama alanı bulan teknolojiler karar destek sistemleri, geniş alan ağlar ve elektronik veri değişimi sistemleri olmuştur. Makine sektöründe ise en düşük uygulama seviyesi barkod okuma ve iletim sistemleridir. Otomotiv sektöründe karar destek sistemleri, kimya sektöründe ise elektronik veri değişimi sistemleri en düşük uygulama seviyesine sahip sistemler olarak görülmektedir.

Tablo 5. İşletmelerin bilişim teknolojileri kullanım düzeyleri*

\begin{tabular}{|c|c|c|c|c|c|c|}
\hline Bilişim teknolojileri & & Gida & Makine & Otomotiv & Kimya & $\begin{array}{l}\begin{array}{l}\text { Genel } \\
\text { ortalama }\end{array} \\
\end{array}$ \\
\hline \multirow{2}{*}{ İnternet } & Ortalama & 4,67 & 4,52 & 4,49 & 4,81 & 4,55 \\
\hline & Std. Sapma & 0,724 & 0,889 & 0,909 & 0,403 & 0,851 \\
\hline \multirow{2}{*}{ Yerel alan ağları (LAN) } & Ortalama & 4,13 & 3,83 & 4,07 & 4,19 & 3,96 \\
\hline & Std. Sapma & 1,457 & 1,442 & 1,237 & 1,047 & 1,348 \\
\hline \multirow{2}{*}{ Barkod okuma ve iletim sistemleri** } & Ortalama & 2,60 & 1,81 & 2,07 & 2,94 & 2,06 \\
\hline & Std. Sapma & 1,882 & 1,272 & 1,582 & 1,526 & 1,482 \\
\hline \multirow{2}{*}{ Karar destek sistemleri } & Ortalama & 2,07 & 1,93 & 1,98 & 2,25 & 1,98 \\
\hline & Std. Sapma & 1,438 & 1,220 & 1,246 & 1,390 & 1,255 \\
\hline \multirow{2}{*}{ Elektronik veri değişimi } & Ortalama & 2,07 & 1,97 & 2,09 & 2,13 & 2,03 \\
\hline & Std. Sapma & 1,486 & 1,282 & 1,229 & 1,408 & 1,285 \\
\hline \multirow{2}{*}{ Kurumsal kaynak planlaması (ERP) } & Ortalama & 3,13 & 2,43 & 2,42 & 2,13 & 2,46 \\
\hline & Std. Sapma & 1,356 & 1,477 & 1,362 & 1,204 & 1,416 \\
\hline \multirow{2}{*}{ Geniş alan ağları (WAN) } & Ortalama & 2,07 & 2,02 & 2,40 & 2,56 & 2,19 \\
\hline & Std. Sapma & 1,163 & 1,422 & 1,438 & 1,632 & 1,430 \\
\hline \multirow{2}{*}{ Uzman sistemler } & Ortalama & 2,80 & 2,24 & 2,56 & 2,25 & 2,39 \\
\hline & Std. Sapma & 1,821 & 1,412 & 1,512 & 1,390 & 1,478 \\
\hline
\end{tabular}

* 1: Hiç uygulamıyor/ 5: İleri seviyede uyguluyor

**ANOVA test sonucuna göre 0,05 seviyesinde sektörler arasında anlamlı farklılık göstermektedir.

Araştırmaya katılan işletmelerin Endüstri 4.0 teknolojilerine ilişkin uygulama durumları ve bu teknolojilere kendi sektörleri bağlamında atfettikleri önem dereceleri Tablo 6'da belirtildiği gibidir. $\mathrm{Bu}$ sonuçlar incelendiğinde uygulama açısından KOBİ'lerin belirtilen teknolojileri uygulama seviyelerinin çok düşük olduğunu göstermektedir. Sektörler arası farklılıkların incelenmesi için yapılan ANOVA test sonucuna göre ise sadece nesnelerin interneti teknoloji uygulamalarının sektörler arasında anlamlı farklılık gösterdiği tespit edilmiştir $(\mathrm{p}<0,005)$. Aynı teknoloji sinıflandırmasına atfedilen önem dereceleri incelendiğinde ise her bir teknoloji sınıfının yüksek önem derecesinde değerlendirildiği görülmektedir. Elde edilen sonuçlar 1şı̆̆ında her ne kadar araştırmaya katılan işletmelerin çeşitli sebeplerden (yapısal, finansal, yönetimsel, işgücü vb.) dolayı bu teknolojileri uygulamada çok düşük seviyelerde olsalar bile faaliyette bulundukları sektör bağlamında değerlendirdiklerinde her bir teknolojinin sektörün geleceği ve rekabet açısından önemli olduğunu düşündükleri görülmektedir. Kısaca işletmelerin, imkânları olması dâhilinde bu teknolojileri kullanmak istediği söylenebilir.

Tablo 6. Endüstri 4.0 teknolojilerinin ortalama kullanım durumu

\begin{tabular}{|c|c|c|c|c|}
\hline & \multicolumn{2}{|c|}{$\begin{array}{c}\text { Endüstri } 4.0 \text { teknolojileri kullanım } \\
\text { durumu* }\end{array}$} & \multicolumn{2}{|c|}{$\begin{array}{c}\text { Endüstri 4.0 teknolojileri önem } \\
\text { dereceleri durumu** }\end{array}$} \\
\hline & Ortalama & Std. Sapma & Ortalama & Std. Sapma \\
\hline Otonom robotlar & 1,26 & 1,416 & 4,29 & 1,535 \\
\hline Büyük veri uygulamaları & 1,29 & 1,314 & 3,87 & 1,726 \\
\hline Bulut-bilişim teknolojisi & 1,41 & 1,583 & 3,94 & 1,714 \\
\hline Siber güvenlik önlemleri & 1,60 & 1,772 & 4,31 & 1,465 \\
\hline Simülasyon (benzetim) teknolojisi & 1,82 & 5,392 & 4,06 & 1,588 \\
\hline
\end{tabular}




\begin{tabular}{|c|c|c|c|c|}
\hline Eklemeli üretim sistemleri & 1,28 & 1,571 & 3,83 & 1,654 \\
\hline Sistem bütünleştirme & 1,90 & 1,881 & 3,87 & 1,716 \\
\hline Nesnelerin interneti teknolojisi $* * *$ & 1,82 & 1,784 & 3,97 & 1,675 \\
\hline Artırılmış gerçeklik teknolojisi & 1,13 & 1,385 & 4,05 & 1,620 \\
\hline Siber-fiziksel sistemler & 1,49 & 1,499 & 4,03 & 1,660 \\
\hline
\end{tabular}

Araştırma amacına uygun olarak işletmelere, kurum içindeki hangi departmanlarda Endüstri 4.0 teknolojilerini kullandıklarını belirtmeleri istenmiştir. İşletmelerin vermiş oldukları cevapların ortalaması ve orta ve ileri düzeyde bu teknolojileri kullanan işletmelerin sayıları Tablo 7 ve 8 'de özetlenmiştir. Buna göre Endüstri 4.0 teknolojilerini belirtilen 9 departmanda uygulama seviyeleri göreceli olarak temel düzeyde de olsa uygulandığı yönünde olmuştur. Bu sonuç Endüstri 4.0 teknolojilerinin uygulanma seviyeleri ile kıyaslandığında örneklemi oluşturan KOBI'lerin kendilerini olduklarından daha iyi bir seviyede algıladıklarını göstermektedir.

Tablo 7. Endüstri 4.0 teknolojileri departmanlar açısından ortalama kullanım düzeyleri*

\begin{tabular}{|c|c|c|c|c|c|c|}
\hline Departmanlar & & Gida & Makine & Otomotiv & Kimya & $\begin{array}{l}\text { Genel } \\
\text { ortalama }\end{array}$ \\
\hline \multirow{2}{*}{ Araştırma-Geliştirme } & Ortalama & 2,40 & 1,97 & 2,04 & 2,06 & 2,03 \\
\hline & Std. Sapma & 1,298 & 1,364 & 1,362 & 0,998 & 1,325 \\
\hline \multirow{2}{*}{ Üretim } & Ortalama & 2,73 & 2,22 & 2,46 & 2,31 & 2,35 \\
\hline & Std. Sapma & 1,534 & 1,560 & 1,615 & 1,195 & 1,543 \\
\hline \multirow{2}{*}{ Satın Alma } & Ortalama & 2,27 & 1,96 & 1,75 & 1,75 & 1,90 \\
\hline & Std. Sapma & 1,223 & 1,359 & 1,074 & 0,856 & 1,226 \\
\hline \multirow{2}{*}{ Lojistik** } & Ortalama & 2,33 & 1,62 & 1,40 & 1,50 & 1,60 \\
\hline & Std. Sapma & 1,397 & 1,108 & 0,821 & 0,817 & 1,050 \\
\hline \multirow{2}{*}{ Satış-Pazarlama } & Ortalama & 2,27 & 2,06 & 1,88 & 2,06 & 2,02 \\
\hline & Std. Sapma & 1,335 & 1,397 & 1,324 & 1,436 & 1,366 \\
\hline \multirow{2}{*}{ Bakım-Onarım } & Ortalama & 2,27 & 1,96 & 1,82 & 1,81 & 1,93 \\
\hline & Std. Sapma & 1,280 & 1,414 & 1,297 & 0,981 & 1,330 \\
\hline \multirow{2}{*}{ Bilişim Teknolojileri } & Ortalama & 2,53 & 1,85 & 1,86 & 2,13 & 1,93 \\
\hline & Std. Sapma & 1,506 & 1,303 & 1,187 & 1,408 & 1,299 \\
\hline \multirow{2}{*}{ Muhasebe-Finansman } & Ortalama & 2,67 & 2,32 & 2,09 & 2,25 & 2,27 \\
\hline & Std. Sapma & 1,633 & 1,594 & 1,503 & 1,653 & 1,569 \\
\hline \multirow{2}{*}{ Ürün Tasarımı } & Ortalama & 2,07 & 2,15 & 2,04 & 2,06 & 2,10 \\
\hline & Std. Sapma & 1,335 & 1,510 & 1,476 & 1,237 & 1,453 \\
\hline
\end{tabular}

Tablo 8. Departmanlara göre Endüstri 4.0 teknolojilerini orta ve ileri düzeyde kullanan işletme sayısı

\begin{tabular}{lll}
\hline Departmanlar & Orta ve ileri düzeyde kullanan işletme sayısı & Yüzde (\%) \\
\hline Üretim & 78 & 42,3 \\
Araştırma-Geliştirme & 72 & 39,2 \\
Muhasebe-Finansman & 72 & 39,1 \\
Ürün Tasarımı & 62 & 33,7 \\
Satış-Pazarlama & 60 & 32,6 \\
Bilişim Teknolojileri & 59 & 32,1 \\
Bakım-Onarım & 56 & 30,4 \\
Satın Alma & 55 & 29,8 \\
Lojistik & 36 & 19,6 \\
\hline
\end{tabular}

İşletmelerin nesnelerin interneti teknolojileri olarak belirtilen 5 teknoloji [41] uygulamasına ilişkin kullanım düzeyleri ve orta ve ileri düzeyde bu teknolojileri kullanan KOBI'lerin sayıları Tablo 9 ve Tablo 10'da özetlenmiştir. Elde edilen sonuçlara göre KOBİ'lerin belirtilen teknolojileri kullanım düzeyleri göreceli olarak olumlu yöndedir. Özellikle sensör teknolojisi en ileri düzeyde kullanılan teknoloji olarak gözükmektedir. Sensör teknolojisinin diğer teknolojilere kıyasla ulaşılabilirliğinin fazla olması ve maliyet açısından diğer teknolojilere kıyasla daha ucuz olması bu durumun sebepleri arasında gösterilebilir. Dolayısıyla KOBI'lerin kaynaklarının yettiği, erişebildikleri teknolojileri ağırlıklı olarak kullandıkları söylenebilmektedir. 
Tablo 9. Sektörlere göre nesnelerin interneti teknolojilerinin ortalama kullanım düzeyleri*

\begin{tabular}{|c|c|c|c|c|c|c|}
\hline \multicolumn{2}{|l|}{ Nesnelerin interneti teknolojileri } & \multirow{2}{*}{$\frac{\text { Gida }}{2,73}$} & \multirow{2}{*}{$\begin{array}{l}\text { Makine } \\
2,23\end{array}$} & \multirow{2}{*}{$\begin{array}{l}\text { Otomotiv } \\
2,02\end{array}$} & \multirow{2}{*}{$\begin{array}{l}\text { Kimya } \\
2,25\end{array}$} & \multirow{2}{*}{$\begin{array}{l}\begin{array}{l}\text { Genel } \\
\text { ortalama }\end{array} \\
221\end{array}$} \\
\hline Makineden makineye iletişim araçları & Ortalama & & & & & \\
\hline$(\mathrm{M} 2 \mathrm{M})$ & Std. Sapma & 1,58 & 1,395 & 1,382 & 1,291 & 1,399 \\
\hline \multirow{2}{*}{ Sensör teknolojisi } & Ortalama & 3,47 & 3,16 & 2,88 & 2,81 & 3,07 \\
\hline & Std. Sapma & 1,407 & 1,447 & 1,536 & 1,223 & 1,455 \\
\hline \multirow{2}{*}{ RFID (radyo frekansı ile tanımlama) } & Ortalama & 2 & 1,78 & 1,32 & 1,5 & 1,63 \\
\hline & Std. Sapma & 1,309 & 1,296 & 0,948 & 0,894 & 1,181 \\
\hline \multirow{4}{*}{$\begin{array}{l}\text { Depo otomasyon sistemleri (otomatik } \\
\text { raflar vb.) } \\
\text { Gerçek zamanlı yer belirleme sistemleri } \\
\text { (GPS vb.)** }\end{array}$} & Ortalama & 1,87 & 1,53 & 1,35 & 1,75 & 1,52 \\
\hline & Std. Sapma & 1,457 & 0,991 & 0,916 & 1,125 & 1,028 \\
\hline & Ortalama & 2,33 & 1,59 & 1,33 & 1,44 & 1,55 \\
\hline & Std. Sapma & 1,759 & 1,082 & 0,873 & 0,727 & 1,09 \\
\hline
\end{tabular}

* 1: Hiç uygulamıyor/ 5: İleri seviyede uyguluyor

**ANOVA test sonucuna göre 0,05 seviyesinde sektörler arasında anlamlı farklılık göstermektedir.

İşletmelerin nesnelerin interneti teknolojilerini orta ve ileri düzey kullanımlarına bakıldığında ise yine Endüstri 4.0 teknolojilerinin kullanım düzeylerinde elde edilen sonuçlar ile benzer sonuçlar elde edildiği söylenebilir. Her ne kadar Tablo 10'da belirtilen teknolojileri orta ve ileri seviyelerde kullanan işletme sayıları olumlu KOBİ'ler bağlamında olumlu gözükse de genel Endüstri 4.0 teknolojilerini kulanım düzeyleri ile kıyaslandığında bu işletmelerin kendilerini teknolojik sinıflandırmada mevcut seviyelerinden daha ileri seviyede konumlandırdıklarını göstermektedir.

Tablo 10. Nesnelerin interneti teknolojilerini orta ve ileri düzeyde kullanan işletme sayısı

\begin{tabular}{lcc}
\hline Nesnelerin interneti teknolojileri & Orta ve ileri düzeyde kullanan işletme sayısı & Yüzde (\%) \\
\hline Sensör teknolojisi & 130 & 70,2 \\
Makineden makineye iletişim araçları (M2M) & 72 & 38,9 \\
RFID (radyo frekansı ile tanımlama) & 35 & 18,9 \\
Depo otomasyon sistemleri (otomatik raflar vb.) & 31 & 16,7 \\
Gerçek zamanlı yer belirleme sistemleri (GPS vb.) & 32 & 17,3 \\
\hline
\end{tabular}

Endüstri 4.0 ile ilgili bir diğer önemli teknoloji ise bulut bilişim uygulamalarıdır. Araştırmaya katılan KOBİ'lerin bulut bilişim teknolojileri [40] kullanım durumları Tablo 11'de belirtilmiştir. Buna göre KOBI'lerin \%35,8'si veri depolama ve yedeklemede bulut bilişim teknolojilerini kullandığını belirtmiştir.

Tablo 11. Bulut bilişim teknolojileri kullanan işletme sayıları

\begin{tabular}{lcc}
\hline \multicolumn{1}{c}{ Bulut bilişim kullanım alanları } & İşletme sayısı & Yüzde (\%) \\
\hline Veri depolama ve yedekleme & 66 & 35,8 \\
Veri analizi & 16 & 8,6 \\
İşletim desteği ve yazılım geliştirme & 11 & 5,9 \\
Makina ve cihazlar üzerine gömülü bilişim sistemleri & 14 & 7,6 \\
Hiçbiri & 111 & 60 \\
\hline
\end{tabular}

İmalat sanayinde faaliyet gösteren işletmelerin üretim ve lojistik faaliyetlere ilişkin büyük veri ile müşteri kaynaklı çeşitli verileri toplayıp kullanması, ürün kalitesinin artırılması; tedarik zinciri riskinin ve lojistik faaliyetlerin etkin yönetilmesi gibi çok sayıda fayda içermektedir [42]. Bu çerçevede işletmelerin belirtilen verileri kullanım düzeyleri ortalaması ve kullanan işletme sayıları Tablo 12 ve Tablo 13'de özetlenmiştir. Sonuçlar incelendiğinde KOBI'lerin veri kullanımı ile ilgili farkındalık sahibi olduğu göreceli olarak söylenebilmektedir. Özellikle müşterilere ve üretim süreçlerine ilişkin verilerin toplanması ile ilgili olarak tüm sektörlerde bir farkındalık olduğu görülmektedir. İşletmelerin yaklaşık olarak \%64'ü müşteri verilerinin toplanmasını, yaklaşık \%70'i ise üretim esnasında makine ve süreç verilerinin toplanması uygulamalarını orta ve ileri düzeyde uyguladıklarını belirtmiştir.

Tablo 12. Ortalama veri kullanım düzeyi*

\begin{tabular}{llccccccc}
\hline Veri kaynakları & & & Gida & Makine & Otomotiv & Kimya & $\begin{array}{c}\text { Genel } \\
\text { ortalama }\end{array}$ \\
\hline $\begin{array}{l}\text { Müşșteri verilerinin } \\
\text { alı̧̧anlıkları vb.) }\end{array}$ & \multirow{2}{*}{ toplanması } & \multirow{2}{*}{ (Tüketim } & Ortalama & 3,53 & 3,18 & 3,16 & 3,06 & 3,19 \\
& & & Std. Sapma & 1,767 & 1,399 & 1,486 & 1,482 & 1,457
\end{tabular}




\begin{tabular}{|c|c|c|c|c|c|c|}
\hline \multirow{2}{*}{$\begin{array}{l}\text { Üretim esnasında makine ve süreç verilerinin } \\
\text { toplanması }\end{array}$} & Ortalama & 3,08 & 2,89 & 3,36 & 3 & 3,05 \\
\hline & Std. Sapma & 1,553 & 1,272 & 1,454 & 1,506 & 1,373 \\
\hline \multirow{2}{*}{$\begin{array}{l}\text { Lojistik faaliyetlere ilişkin verilerin eş zamanlı } \\
\text { toplanması (Dağıtım araçlarının konumlarının takip } \\
\text { edilmesi vb.) }\end{array}$} & Ortalama & 2,2 & 2,34 & 2 & 2,56 & 2,24 \\
\hline & Std. Sapma & 1,568 & 1,316 & 1,21 & 1,59 & 1,332 \\
\hline \multirow{2}{*}{$\begin{array}{l}\text { Ekonomik, sosyal ve siyasal gelişmelere ve müşteri } \\
\text { eğilimlerine ait verilerin diş kaynaklardan temini }\end{array}$} & Ortalama & 2,8 & 2,59 & 2,45 & 2,31 & 2,54 \\
\hline & Std. Sapma & 1,612 & 1,347 & 1,278 & 1,537 & 1,36 \\
\hline
\end{tabular}

Tablo 13. Sektörlere göre veri kullanımı orta ve ileri düzeyde olan işletme sayısı

\begin{tabular}{|c|c|c|c|c|c|c|}
\hline Veri kaynakları & $\begin{array}{l}\text { İşletme } \\
\text { sayısı (n) } \\
\text { Yüzde (\%) }\end{array}$ & Gida & Makine & Otomotiv & Kimya & $\begin{array}{l}\text { Genel } \\
\text { toplam }\end{array}$ \\
\hline toplanmas1 & $\mathrm{n}$ & 9 & 61 & 38 & 10 & 120 \\
\hline alışkanlıkları vb.) & $\%$ & 0,6 & 0,65 & 0,67 & 0,63 & 64,86 \\
\hline Üretim esnasında makine ve süreç verilerinin & $\mathrm{n}$ & 9 & 60 & 36 & 11 & 118 \\
\hline toplanmas1 & $\%$ & 0,69 & 0,65 & 0,72 & 0,69 & 67,82 \\
\hline Lojistik faaliyetlere ilişkin verilerin eş zamanlı & $\mathrm{n}$ & 4 & 39 & 18 & 7 & 70 \\
\hline $\begin{array}{l}\text { toplanması (Dağıtım araçlarının konumlarının takip } \\
\text { edilmesi vb.) }\end{array}$ & $\%$ & 0,27 & 0,41 & 0,32 & 0,44 & 37,84 \\
\hline Ekonomik, sosyal ve siyasal gelişmelere ve müşteri & $\mathrm{n}$ & 8 & 46 & 27 & 7 & 89 \\
\hline eğilimlerine ait verilerin dış kaynaklardan temini & $\%$ & 0,53 & 0,49 & 0,48 & 0,45 & 48,37 \\
\hline
\end{tabular}

Veri kullanım düzeylerinin yanı sıra elde edilen verilerin saklanma yöntemleri de Endüstri 4.0 ile öne çıkan diğer unsurlar arasındadır [40]. Araştırma kapsamındaki KOBI'lerin veri saklama durumları incelendiğinde yaklaşık \%60'ının verilerini yerel bir bilgisayarın internet bağlantısıyla, yaklaşık \%30'unun çevrimdışı sistemleri ile sakladıkları belirlenmiştir. Kullanılan diğer yöntemler ise çevrimiçi sistemler, güvenli çevrimiçi sağlayıcılar (Bulut teknolojileri) ve ortak bir veri tabanı kullanımı şeklindedir.

KOBİ'lerin sistem bütünleştirme uygulamalarına yaklaşımları incelendiğinde ise sistem bütünleştirme uygulamalarını işletme içerisinde orta ve ileri seviyede kullanan işletmelerin oranının $\% 43$, işletme dış1 ise $\% 30$ olduğu görülmüștür. $\mathrm{Bu}$ sonuç Endüstri 4.0 teknoloji düzeyini yakalama açısından yeterli seviyelere ulaşamamış olsa bile KOBİ'ler açısından göreceli olarak dijitalleşme yolunda olumlu gidişatı gösterdiği söylenebilmektedir.

\section{SONUÇ}

$\mathrm{Bu}$ çalışmada Konya imalat sanayiinde faaliyet gösteren KOBİ'lerin teknoloji uygulama seviyelerinin belirlenmesi amaçlanmıştır. $\mathrm{Bu}$ amaçla belirlenen 4 sektörden toplam 185 işletme ile görüşmeler gerçekleştirilmiştir. İncelenen işletmelerin büyük çoğunluğu makine ve otomotiv imalat sanayii işletmeleri olup, daha çok küçük işletme (10-49 çalışan) ölçeğindedir. Teknoloji kullanımı ile ilgili öncelikli olarak imalat teknolojileri değerlendirmeye alınmıştır. İmalat teknoloji kullanım düzeyleri incelendiğinde işletmelerin genel olarak orta üstü seviyede bu teknolojileri kullandıkları gözlenmiştir. İmalat teknolojileri açısından sonuçlar değerlendirildiğinde işletmelerin gerek bölgesel gerekse sektörel açıdan değerlendirildiğinde temel teknoloji kullanımında göreceli olarak iyi bir konumda oldukları söylenebilir. Değerlendirmeye alınan bir diğer teknolojik uygulama kriteri ise bilişim teknolojileridir. İncelenen işletmelerdeki bilişim teknolojileri kullanım düzeylerine ilişkin veriler incelendiğinde seviyede işletmelerin ortalama bir düzeye sahip olduğu görülmektedir. Bu teknolojiler içerisinde internet ve yerel alan ağları kullanım düzeyleri oldukça yüksek bir seviye göstermiştir. Bu durum bilişim teknolojileri sınıfı içerisinde bu teknolojilerin temel teknolojiler olması ve çağımız teknolojik gelişimleri açıdan değerlendirildiğinde normal bir durum olarak değerlendirilebilir. Elde edilen sonuçlar Konya'daki imalat sanayii KOBI'lerinin bilişim ve imalat teknolojileri uygulama düzeyleri değerlendirildiğinde belirlenen sektörlerin, Endüstri 4.0 dönüşümü açısından henüz başlangıç düzeyinde olduğu söylenebilir. Ebetteki her teknolojinin her sektörde tam kapasite kullanımı söz konusu olmayabilir. $\mathrm{Bu}$ teknolojilerin sektörlerin gereksinimleri açısından değişiklik göstermeleri normal bir durumdur. Ancak sonuçlardan hareketle sektörlerin kendileri ile ilgili teknolojilerinden bile tam anlamıla yararlanmadıkları söylemek yanlış olamayacaktır.

KOBI'lerin Endüstri 4.0 teknolojileri uygulama düzeyleri incelendiğinde ise kullanım düzeyinin oldukça düşük olduğu görülmektedir. Belirtilen teknolojilerinin düşük seviyede de olsa yine uygulanıyor olması dijitalleşme sürecine geçişte bir adım atıldığını göstermektedir. Elde edilen sonuçlar başta TUSİAD (2016) ve Berger (2017) gibi uluslararası kuruluşların Türkiye'deki sanayi sektörüne ilişkin raporlarında elde edilen sonuçlar ve Şahin (2019), Çevik (2019) gibi Türkiye ile ilgili yapılan bilimsel çalışmaların sonuçları ile paralellik 
göstermektedir. İşletmelerin bu teknolojilere atfettikleri önem dereceleri değerlendirildiğinde ise teknolojilerin kullanım düzeyinin çok düşük olmasına rağmen her teknolojiye verilen önem seviyesinin yüksek olduğu tespit edilmiştir. Bu durum işletme yöneticilerinin ve mühendislerinin yarının ihtiyaçları hakkında farkındalık sahibi olduğunu göstermektedir. Yani sadece vizyon sahibi değil aynı zamanda faaliyet gösterdikleri sektörün geleceği ve rekabet şartları açısından yönetim bilincine sahip olduklarını göstermektedir. Bu sonuç çalışmanın ortaya koyduğu önemli sonuçlardan bir tanesidir. Endüstri 4.0 sürecinin önemine ve sürecin sektör ve işletme açısından sağlayacağı katma değere yönelik farkındalık sonuçları Kamber ve Bolatan [36] gibi Endüstri 4.0 farkındalığı üzerine yapılmış çalışmaların sonuçları ile örtüşmektedir.

Endüstri 4.0 teknolojilerinin uygulandığı departmanlar incelendiğinde ise temel seviyede de olsa belirlenen her departmanda uygulandığı yönünde bir sonuca varılmıştır. İşletmeler, teknoloji uygulama düzeylerinin düşük olduğunu belirtmiş olmalarına rağmen aynı değerlendirmeyi departmanlar açısından yaptıklarında konuya daha olumlu yaklaşmışlardır. Bu sonuç da aslında işletmelerin kendilerini teknoloji kullanım düzeyi açısından olduğundan daha fazla iyi (overestimation) değerlendirdiğini göstermektedir. Benzer sonuçlar nesnelerin interneti teknolojileri kullanım düzeyleri incelemelerinde de gözlenmiştir. İncelenen işletmeler nesnelerin interneti teknolojileri kullanımı konusunda kendilerini olduğundan daha iyi bir seviye konumlandırmaktadır. $\mathrm{Bu}$ teknolojiler içerisinde sensör teknolojilerinin kullanımı diğer teknolojilere kıyaslandığında yüksek düzeyde kullanım seviyesi elde etmektedir. Bu durum teknolojilere ulaşılabilirlik ve maliyet açısından değerlendirildiğinde, sensör teknolojisinin diğer teknolojilere kıyasla daha ucuz, erişilebilir ve kolay anlaşılabilir olması ile açıklanabilir.

Endüstri 4.0 ile gündeme gelen teknolojilerin işlevselliğinin ana kaynağı veridir. Sistemlerin etkin çalışması birbirleri arasındaki veri iletişiminin etkin, anlık ve doğru şekilde sağlanabilmesinde gizlidir. Dolayısıyla dijital bir iş dünyasında incelenmesi gereken bir diğer önemli teknoloji bulut bilişim ve veri sistemleri kullanımıdır. Bu teknolojiler işletmelerin Endüstri 4.0 teknoloji uygulama seviyelerinin önemli bir göstergesini oluşturmaktadır. İncelenen işletmelerin bulut bilişim teknolojileri kullanım düzeyleri değerlendirildiğginde, yarısına yakınının belirlenen teknolojileri kullandığı görülmüştür. Özellikle veri kullanım düzeyleri tüm sektörlerde göreceli olarak olumlu sonuçlar göstermiş̧ir. İşletmelerin müşteri ve üretim süreçlerine ilişkin verileri, orta ve üzeri düzeyde topladığı elde edilen sonuçlar arasındadır. Bu sonuç işletmelerin, Endüstrilerin geleceğinin şekillenmesinde çok büyük önem taşıyan veri ve veri analizi

\begin{abstract}
konularında farkındalık sahibi olduklarını göstermektedir.
\end{abstract}

Çalışma sonuçları genel olarak değerlendirildiğinde, incelenen işletmelerin mevcut imalat ve bilişim teknolojilerinde göreceli olarak orta düzey kullanım konumuna sahipken, Endüstri 4.0 teknolojileri uygulamalarında çok düşük düzeyde kaldığı görülmektedir. Bu durum gerek sektörel gerekse ölçek açısından değerlendirildiğinde, Endüstri 4.0'a geçiş sürecinde KOBI'lerin uzun bir yol kat etmesi gerekliliğini göstermektedir. İncelenen işletmeler temel alınarak, henüz Endüstri 3.0 göstergesi olan mevcut imalat ve bilişim teknolojilerinin kullanımında bile ileri seviyelere ulaşılmadığı düşünüldüğünde, Endüstri 4.0 teknolojileri kullanım düzeyinin henüz düşük seviyelerde olması çok şaşırtıcı bir sonuç olarak gözükmemektedir.

Yapılan bu çalışmanın sonuçları temel alındığında iki temel öneri ortaya konulmak istenmektedir. İlk öneri yapılacak olan yeni çalışmalara yöneliktir. Endüstri 4.0 ile ilgili yeni yapılacak çalışmalarda gerek küçük ve orta ölçekli işletmeler gerek ise büyük ölçekli işletmeler bazında Endüstri 4.0 teknoloji kullanımının daha geniş bir sektör ağı açısından değerlendirilmesi ve daha geniş bir perspektiften sürecin tüm boyutları ile değerlendirilmesi önerilmektedir. Diğer bir deyişle, KOBİ'lerin Endüstri 4.0 dönüşümünün, ileri teknoloji kullanımının yanında, yönetim stratejileri, çevresel etki ve insan kaynağı istihdamı açısından da incelenmesi gerekmektedir. Bir diğer öneri ise konu ile ilgili politikaların ve ekonomik süreçlerin geliştirilmesinden sorumlu olan kurum ve kuruluşlarla ilgilidir. Özellikle bilgi birikimi, yazılım ve donanım imkânları, eğitimli ve yetenekli insan kaynağı ve yatırım sermayesi vb. başlıca kaynakları yeterli düzeyde olmayan KOBI'lerin yaşanmakta olan dijital dönüşüme uyum sağlaması için çeşitli desteklere ihtiyaç duyduğu gözlemlenmektedir. KOBİ'lerin bu süreçte kendi stratejilerini geliştirebilmeleri için bu yeni teknolojilerin, işletmeleri ve sektörleri açısından ne gibi tehdit ve faydaları içerdiğini tam olarak anlamaları büyük önem taşımaktadır. $\mathrm{Bu}$ geçiş sürecinin KOBI'lerin lehine işlemesi ve rekabet güçlerini artırması adına, sürece ilişkin bilinçlendirme ve bilgilendirme çalışmalarının yapılmasına olanak verecek, KOBİ'lere özel danışmanlık merkezlerinin kurulmasının hem sektörlerin hem de ülkelerin ekonomik sürdürülebilirliği açısından faydalı olacağı düşünülmektedir.

\section{TEŞEKKÜR}

$\mathrm{Bu}$ çalışma Konya Gıda ve Tarım Üniversitesi, Bilimsel Araştırma Projeleri (BAP) Koodinatörlüğü tarafindan desteklenmiş̧ir.

\section{KAYNAKLAR}

[1] Gabaçl1, N., ve Uzunöz, M. (2017). IV. Sanayi devrimi: Endüstri 4.0 ve otomotiv sektörü. In ICPESS 
(International Congress on Politic, Economic and Social Studies), Ankara Yıldırım Beyazıt ÜniversitesiAnkara, Türkiye, 9-11 Kasım.

[2] Pamuk, N. S., ve Soysal, M. (2018). Yeni sanayi devrimi Endüstri 4.0 üzerine bir inceleme. Verimlilik Dergisi, (1), 41-66.

[3] Soylu, A. (2018). Endüstri 4.0 ve Girişimcilikte Yeni Yaklaşımlar. Soylu, A. (2018). Endüstri 4.0 Ve Girişimcilikte Yeni Yaklaşımlar. Pamukkale Üniversitesi Sosyal Bilimler Enstitüsü Dergisi, (32), 43-57.

[4] Özsoylu, A. F. (2017). Endüstri 4.0. Çukurova Üniversitesi Iktisadi ve İdari Bilimler Fakültesi Dergisi, 21(1), 41-64.

[5] Zheng, P., Sang, Z., Zhong, R. Y., Liu, Y., Liu, C., Mubarok, K. ve Xu, X. (2018). Smart manufacturing systems for Industry 4.0: Conceptual framework, scenarios, and future perspectives. Frontiers of Mechanical Engineering, Vol. 13, No. 2, 137-150.

[6] Benias, N., ve Markopoulos, A. P. (2017). A review on the readiness level and cyber-security challenges in Industry 4.0. South Eastern European Design Automation, Computer Engineering, Computer Networks and Social Media Conference (SEEDACECNSM). Kastoria, Greece, 02 November 2017.

[7] Rojko, A. (2017). Industry 4.0 concept: background and overview. International Journal of Interactive Mobile Technologies (iJIM), 11(5), 77-90.

[8] Rao, T. R., Mitra, P., Bhatt, R. ve Goswami, A. (2018). The big data system, components, tools, and technologies: a survey. Knowledge and Information Systems, (60), 1-81.

[9] Purcell, B. M. (2014). Big data using cloud computing. Journal of Technology Research, 5(1).

[10] Li, G., Hou, Y. ve Wu, A. (2017). Fourth Industrial Revolution: technological drivers, impacts and coping methods. Chinese Geographical Science, 27(4), 626637.

[11] TUSİAD ve BCG (2016). Industry 4.0 in Turkey as an Imperative for Global Competitiveness - An Emerging Market Perspective. https://tusiad.org/en/reports/item/9011-industry-40-inturkey-as-an-imperative-for-global-competitiveness.

[12] Ceruti, A., Marzocca, P., Liverani, A., ve Bil, C. (2019). Maintenance in Aeronautics in an Industry 4.0 Context: The Role of Augmented Reality and Additive Manufacturing. Journal of Computational Design and Engineering. 6(4), 516-526.

[13] Gibson, I., Rosen, D. W., ve Stucker, B. (2010). Design for additive manufacturing. In: Additive manufacturing Technologies, Springer, Boston, MA., 299-332.

[14] Manogaran, G., Thota, C., Lopez, D. ve Sundarasekar, R. (2017). Big data security intelligence for healthcare Industry 4.0, In: Thames, L., Schaefer, D (ed.), Cybersecurity for Industry 4.0, Springer, Cham, 103-126.

[15] Bahrin, M. A. K., Othman, M. F., Azli, N. N., ve Talib, M. F. (2016). Industry 4.0: A review on industrial automation and robotic. Jurnal Teknologi, 78(6-13), 137-143.

[16] Rejikumar, G., Arunprasad, P., Persis, J., ve Sreeraj, K. M. (2019). Industry 4.0: key findings and analysis from the literature arena. Benchmarking: An International Journal. 26(8).

[17] Boston Danışma Grubu (BCG), (2019). Embracing Industry 4.0 rediscovering growth, https://www.bcg.com/capabilities/operations/embracin g-Industry-4.0-rediscovering-growth.aspx.

[18] Lee, J., Bagheri, B., ve Kao, H. A. (2015). A cyberphysical systems architecture for industry 4.0-based manufacturing systems. Manufacturing letters, 3, 1823.

[19] Yıldız, A. (2018). Endüstri 4.0 ve akıllı fabrikalar. Sakarya University Journal of Science, 22(2), 546-556. [20] Firat, O. Z., ve Fırat, S. Ü. (2017). Endüstri 4.0 yolculuğunda trendler ve robotlar. İstanbul Üniversitesi İşletme Fakültesi Dergisi, 46(2), 211-223.

[21] Özdoğan, O. (2017). Endüstri 4.0: Dördüncü Sanayi Devrimi ve Endüstriyel Dönüşümün Anahtarları. Pusula Yayıncılık.

[22] Ulusoy, G. (2018). İmalat sektöründe Endüstri 4.0 dönüşümü çabaları: bazı gözlemler. Iktisat ve Toplum, 8(92), 121-123.

[23] Safar, L., Sopko, J., Bednar, S., ve Poklemba, R. (2018). Concept of SME business model for industry 4.0 environment. TEM Journal, 7(3), 626.

[24] Sevinç, A., Gür, Ş., ve Eren, T. (2018). Analysis of the Difficulties of SMEs in Industry 4.0 Applications by Analytical Hierarchy Process and Analytical Network Process. Processes, 6(12), 264.

[25] Schröder, C. (2016). The challenges of industry 4.0 for small and medium-sized enterprises. FriedrichEbert-Stiftung: Bonn, Germany.

[26] Çevik, D. (2019). KOBİ'lerde Sanayi 4.0'ın Uygulanabilirliği ve Yönetici Bakış Açılarının Değerlendirilmesi. Uluslararası Bilimsel Araştırmalar Dergisi (IBAD), 4(2), 277-291.

[27] Mittal, S., Khan, M. A., Romero, D., ve Wuest, T. (2018). A critical review of smart manufacturing \& Industry 4.0 maturity models: Implications for small and medium-sized enterprises (SMEs). Journal of manufacturing systems, 49, 194-214

[28] Schumacher, A., Erol, S., ve Sihn, W. (2016). A maturity model for assessing Industry 4.0 readiness and maturity of manufacturing enterprises. Procedia Cirp, $52,161-166$.

[29] Müller, J. M., ve Voigt, K. I. (2018). Sustainable industrial value creation in SMEs: A comparison between industry 4.0 and made in China 2025. International Journal of Precision Engineering and Manufacturing-Green Technology, 5(5), 659-670.

[30] Özçelik, T. O., Erkollar, A., ve Cebeci, H. I. (2019). Bir İmalat İşletmesi için Endüstri 4.0 (Dijital) Olgunluk Seviyesi Belirleme Uygulaması. 5th International Management Information Systems Conference, Ankara, 24-26 Ekim 2018. 
[31] Infosys (2015). Industry 4.0: The State of the Nations, http://www.experienceinfosys.com/industry4-0.

[32] Berger (2017). Challenge for the F\&B industry in Turkey, advantage or competitive disadvantage? https://www.siemens.com.tr/i/Assets/gidagunu/170524_KS_Industrie40_Presentation_Siemens_ Turkey.pdf.

[33] Deloitte (2017). The Fourth Industrial Revolution is here-are you ready? https://www2.deloitte.com/content/dam/Deloitte/tr/Do cuments/manufacturing/Industry4-0_Are-youready_Report.pdf.

[34] Europarl (2016). Industry 4.0. http://www.europarl.europa.eu/RegData/etudes/STUD /2016/570007/IPOL_STU(2016)570007_EN.pdf

[35] Şahin, C. (2019). Ülkelerin endüstri 4.0 düzeylerinin COPRAS yöntemi ile analizi: G-20 ülkeleri ve Türkiye. Yüksek Lisans Tezi, Bartın Üniversitesi, Türkiye.

[36] Kamber, E. ve Bolatan, G. İ. S. (2019). Endüstri 4.0 Türkiye Farkındalığı. Mehmet Akif Ersoy
Üniversitesi Sosyal Bilimler Enstitüsü Dergisi, 11(30), 836-847.

[37] Görçün, Ö. F. (2017). Dördüncü Sanayi Devrimi Endüstri 4.0. İstanbul: Beta.

[38] Bülbül, H., ve Güles, H. K. (2004). Türk sanayi işletmelerinde ileri imalât teknolojileri kullanımı ve performansa etkisi. METU Studies in Development, 31(1), 1 .

[39] Tekin, M., Zerenler, M., ve Bilge, A. (2005). Bilişim teknolojileri kullanımının işletme performansına etkileri: lojistik sektöründe bir uygulama. Istanbul Ticaret Üniversitesi Fen Bilimleri Dergisi, 4(8), 115-129.

[40] Özkurt, C. (2016). Endüstri 4.0 Perspektifinden Türkiye'de İmalat Sanayinin Durumu: Sakarya İmalat Sanayi Üzerine Bir Anket Çalışması. Yüksek Lisans Tezi, Sakarya Üniversitesi, Türkiye.

[41] Atzori, L., Iera, A., \& Morabito, G. (2010). The internet of things: A survey. Computer networks, 54(15), 2787-2805.

[42] Body, K., 2018, 10 big data use cases in manufacturing, https://www.actify.com/industrytopics/10-big-data-use-cases-manufacturing/ 